\title{
Estadios de la otredad en la reflexión filosófica de Luis Villoro
}

\author{
MARIO TEODORO RAMíREZ \\ Facultad de Filosofía "Samuel Ramos" \\ Universidad Michoacana de San Nicolás de Hidalgo \\ marioteo56@yahoo.com.mx
}

\begin{abstract}
Resumen: Este ensayo propone interpretar la filosofía entera de Luis Villoro como una filosofía pluralista, progresiva y crítico-racional de la "otredad"; es decir, como una crítica al paradigma "egológico" de la tradición filosóficocultural occidental. Distingo cuatro estadios de la otredad en su obra: 1) el otro como el tú, esto es, la experiencia interpersonal de la otredad; 2) el otro como el "ajeno" o el "extraño", i.e., la experiencia histórico-cultural de la otredad, particularmente referida a la otredad del indígena americano; 3) el Otro absoluto: la experiencia metafísico-religiosa de la otredad; 4) el otro como los otros, esto es, la experiencia comunitaria y el ideal de una comunidad humana armónica y libre. Concluyo ponderando el valor y el significado filosófico y sociocultural de la propuesta de Villoro.
\end{abstract}

Palabras clave: otro, indígena, sagrado, comunidad

\begin{abstract}
This essay interprets Luis Villoro's philosophy as a pluralist and progressive one, with a rationally critical focus on otherness; i.e., as a criticism of the "egological" paradigm of the Western philosophical-cultural tradition. Four states of otherness are distinguished in his work. 1) The other as "you": the interpersonal experience of otherness; 2) the other as "somebody else" or a "stranger", this being the cultural-historic experience of otherness, that particularly refers to the Mexican Indians; 3) the Other as the absolute regarding the metaphysical-religious experience of otherness; 4) the other as "the others", that is, the communitarian experience and the ideal of a human community that is harmonic and free. It concludes with a reflection upon the meaning and value of Villoro's philosophical and socio-cultural proposal.

Key words: other, indigenous, sacred, community
\end{abstract}

\section{Introducción. Una filosofía de la otredad}

La inquietud, la preocupación por el otro ha estado presente a lo largo de la trayectoria filosófica de Luis Villoro, a veces de modo lateral o implícito, a veces de modo directo y explícito. Nuestra hipótesis de trabajo es que tal tema proporciona en realidad una clave importante para entender el sentido de su filosofía y que, considerando el contexto teórico y el modo como lo enfoca, constituye una aportación relevante a la comprensión general del problema de la otredad, ${ }^{1}$ asunto particu-

${ }^{1}$ ¿Otredad o alteridad? Si usamos la primera expresión para designar el "otro" humano en particular y la segunda para designar "lo otro" en general, cualquier 
larmente destacado en la filosofía del siglo veinte y, de hecho, una de las contribuciones de nuestra época a la historia de la filosofía. ${ }^{2}$

Identificamos tres rasgos característicos en la reflexión de Villoro sobre la otredad, que articularán el desarrollo de nuestra exposición.

1. El primer rasgo consiste en una visión plural de la otredad: el otro se dice de varias maneras, o bien, el acceso a la otredad (al otro y a lo otro) atraviesa por distintos estadios o momentos. Básicamente se pueden puntualizar en la reflexión de Villoro cuatro: 1) el estadio interpersonal: el otro yo, el tú, esto es, la experiencia personal de la intersubjetividad de la que se ocupa en sus textos iniciales de corte existencialista; 2) el estadio intercultural: el otro humano que pertenece a "otra" cultura; la alteridad tiene aquí un sentido estructural, sociohistórico, y tiene que ver con los estudios y reflexiones de Villoro sobre la problemática indígena de nuestro país y la temática cultural en general; 3) el estadio metafísico: el Otro absoluto, lo divino o lo sagrado, presente en sus ocasionales pero significativos textos de filosofía de la religión; y, finalmente, 4) el estadio de la praxis social: los otros, la pluralidad, la comunidad humana, ámbito donde de alguna manera se media la pura relación de exterioridad y exclusión entre el yo y el otro, entre la conciencia y el mundo, entre lo humano y lo divino, en fin, entre modernidad y tradición. Este estadio tiene que ver tanto con los textos de teoría del conocimiento como con los de ética y de filosofía política.

2. El segundo rasgo tiene que ver con la visión crítica del ego. Cabe señalar que en el acercamiento al tema de la otredad se combinan en el pensamiento de Villoro dos perspectivas o vías de acceso (no siempre explícitamente planteadas): una primera, positiva y directa, de corte ético-metafísico, que nos abre al otro, en sus distintos estadios o momentos, desde un plano existencial y experiencial; y una segunda, negativa e indirecta, de corte crítico-reflexivo, que se plantea más bien como

otro: el ser, la cosa, lo sagrado, el tiempo, etc., podemos afirmar que la filosofía de Villoro se ocupa de ambos "otros", particularmente de su entrelazamiento sistemático.

${ }^{2}$ El tema - el desafío, en realidad- del "otro" está ausente en la mayor parte de la historia de la filosofía occidental. Después de una aparición elusiva en la dialéctica hegeliana (en la lucha de las autoconciencias), surge como una dificultad casi infranqueable en la fenomenología de Husserl. El existencialismo lo retomará de manera explícita (Heidegger, Sartre, Marcel, Merleau-Ponty) y, a partir de Emmanuel Lévinas, se convertirá en un asunto atendido desde diversas perspectivas y posiciones del pensamiento contemporáneo (psicoanálisis, antropología, historia, pensamiento poscolonial, etcétera).

Diánoia, vol. LII, no. 58 (mayo 2007). 
un cuestionamiento de la primacía y centralidad del "yo" y, en general, de los supuestos y prejuicios egocéntricos de la filosofía occidental. El programa de lo que podemos llamar una paulatina "desegologización" del pensamiento filosófico es reconocible desde los primeros hasta los últimos textos de Villoro. ${ }^{3}$ El proceso entero de su reflexión puede ser descrito como una serie de sucesivos descentramientos, de sucesivos movimientos de autocrítica y apertura hacia algo más, hacia algo otro. De esta manera, para cada uno de los estadios de la otredad que hemos mencionado puede hacerse corresponder un momento autocrítico y descentralizador: 1) descentramiento del "ego" de la filosofía reflexiva de la modernidad y, concomitantemente, de la estructura general de la filosofía moderna en cuanto filosofía de la conciencia y de la reflexión; 2) descentramiento del etnocentrismo del pensamiento y de la cultura occidental, a fin de que lo otro de esta cultura - desconocido, colonizado, dominado - pueda hacerse ver y escuchar (el Oriente, las culturas indígenas de América, etc.); 3) descentramiento de toda concepción del mundo puramente antropocéntrica (logocéntrica) en pos de una experiencia de la otredad en cuanto experiencia de lo "sagrado"; 4) descentramiento de la visión reducidamente positiva e individualista de la sociedad actual hacia el campo de las posibilidades utópicas de una comunidad humana libre, equitativa y justa.

3. El tercer rasgo singulariza el componente racional de la filosofía de la otredad de Villoro. Al constatar que nuestras estructuras de pensamiento y las formas de experiencia establecidas son incapaces de abrirnos el acceso al otro, y que, más bien, nos inducen al falso reconocimiento del otro, a su negación y "destrucción", Villoro concluye que sólo un pensamiento racional reformulado puede permitirnos cuestionar críticamente esas formas y, a la vez, desbrozarnos el camino para la posibilidad de un auténtico reconocimiento del otro y, todavía más, para la construcción práctica de nuevas formas de interrelación humana. La

${ }^{3}$ Desde este punto de vista resulta explicable la relevancia del concepto de "intencionalidad" en los estudios sobre Husserl y Descartes. Villoro realiza una lectura crítica de Descartes (base de todo idealismo moderno) que tiene por motivo (de raigambre husserliano) hacer valer una concepción totalmente "antisustancialista" del ego cogito, en cuanto principio del conocimiento y la reflexión. Cfr. L. Villoro, La idea y el ente en la filosofía de Descartes, 1965 (véanse las referencias completas en la bibliografía). Respecto del propio Husserl, Villoro subraya las implicaciones del concepto de intencionalidad (el que la conciencia esté enteramente dirigida a "algo") para una interpretación antipsicologista y antisustancialista del "campo de inmanencia" de la conciencia fenomenológica. Véanse sus Estudios sobre Husserl (1975), particularmente el ensayo "La reducción a la inmanencia", pp. 51-98. 
función de la razón es, en principio, negativa, indirecta. Ella cuestiona las formas inadecuadas de relación (o de ausencia de relación) con el otro; pero sólo puede señalar hacia las formas adecuadas de esa relación, pues estas formas rebasan por principio el ámbito intelectual y formal de la razón, apuntan al ámbito de la vida emocional y concreta de la experiencia humana. No obstante, reconociendo sus límites, y por esto mismo, la razón todavía puede tratar de comprender e interpretar aquella experiencia, aprender de ella y ayudar a rehacer y reorientar la realidad humana en todas sus dimensiones.

A diferencia de otras filosofías de la otredad — como la de Lévinas-, Villoro parte tanto del hecho de la "no relación" con el otro como de las formas falsas de esa relación. Su cometido es revelador y crítico a la vez. No se conforma con apuntar hacia lo que serían las formas adecuadas, auténticas, de esa relación; busca además, mediante el ejercicio de una razón crítico-vital, prácticamente orientada, explicar y denunciar las formas inválidas de relación con el otro, y contribuir a su superación, esto es, a la construcción de nuevas formas de interrelación humana. ${ }^{4}$ La razón es lo que nos permite, desde el punto de vista de una filosofía de la otredad, pasar del reconocimiento del otro a la constitución, con él, de una nueva relación, de un nuevo entendimiento, de una nueva comunidad. Es lo que nos permite pasar de una ética de la alteridad, del amor al otro, a una política de la comunidad, de la praxis liberada, pues la razón es la única que puede llevar a cabo la "mediación", el diálogo, entre lo mismo y lo otro, entre la experiencia y el pensamiento, entre lo actual y lo posible, a fin de que nuestra comprensión y nuestra acción sean viables y adquieran por esta relación sentido y verdad.

Como resulta claro, la preocupación por la práctica es lo que explica el interés de Villoro por la razón, y lo que explica también que este interés se realice necesariamente mediante una reformulación crítica

\footnotetext{
${ }^{4}$ Reinterpretando el pensamiento de Emmanuel Lévinas, Enrique Dussel ha elaborado una "filosofía de la otredad" desde una perspectiva latinoamericana (periférica de la modernidad) y con un sentido crítico-revolucionario. En el desarrollo temprano de su "filosofía ética de la liberación" es donde Dussel desarrolla de forma más precisa la apropiación latinoamericana de Lévinas. Cfr. E. Dussel, Filosofía ética latinoamericana, II. Accesos hacia una filosofía de la liberación. Más allá de ciertas convergencias espontáneas entre los pensamientos de Dussel y Villoro, persiste entre ellos una diferencia importante de talante o estilo intelectual. Más directo y explícito el primero en cuanto a los compromisos éticos y políticos de la reflexión filosófica, más cauteloso y analítico el segundo, demorándose un poco más en las perplejidades y desafíos que la experiencia y el mundo plantean a nuestra comprensión racional.
} 
del concepto de racionalidad. Esta reformulación deberá permitir, a la vez, construir una razón sensible al otro, esto es, sensible a la razón del otro.

A continuación recorreremos los cuatro estadios de la alteridad que hemos enumerado antes. Hacia la parte final - entre el tercero y el cuarto apartado - constataremos en el pensamiento de Villoro la emergencia de una perspectiva racional reformulada que, como hemos apuntado, es la condición para explorar concretamente los efectos y las consecuencias prácticas de una filosofía de la otredad.

\section{La alteridad personal: el otro yo, el tú}

En los textos juveniles de Villoro se encuentran claramente presentes dos preocupaciones. Por una parte, la crítica a la condición deshumanizada de la sociedad moderna y, por otra, el interés por trascender, apoyado en el existencialismo, los límites de la filosofía reflexiva moderna, en cuanto filosofía del ego cogito, hacia un filosofar de la alteridad, de la relación o de la comunión con el otro.

En el que podemos considerar su primer ensayo filosófico, "Soledad y comunión" (1949), Villoro diagnostica la situación del hombre moderno como una condición de "enajenación", ${ }^{5}$ de aislamiento y soledad, respecto de la cual la idea de "comunión" (de integración, de comunidad) aparece como una posibilidad lejana, casi perdida. Lo que encontramos es un profundo extrañamiento, un distanciamiento, o un enfrentamiento incluso, entre el sujeto y la realidad. Para el pensamiento moderno, explica nuestro filósofo, "todo movimiento de simpatía, de comunicación afectiva con el mundo, se considera pueril ilusión o burdo antropomorfismo". ${ }^{6}$ La sociedad moderna está dominada por una concepción objetivista, instrumental y pragmática, en la que el actuar humano se encuentra enteramente circunscrito al afán de dominio y a la voluntad de tener; esto es, a la obsesión por la posesión, por el haber. ${ }^{7} \mathrm{El}$ antropocentrismo más egoísta —que la modernidad realiza

${ }^{5}$ El impacto del existencialismo en ciertas versiones críticas del marxismo volvieron centrales en la discusión teórica de hace unos años los conceptos de enajenación, alineación, fetichismo, etc., que trajeron a cuento una visión humanista de Marx, cuya influencia se puede observar en el pensamiento de Villoro si bien no de manera explícita.

${ }^{6}$ Luis Villoro, “Soledad y comunión”, p. 116.

${ }^{7}$ Ésta es, marca Villoro, la concepción propiamente burguesa de la existencia. Pues el burgués "es el hombre que todo lo posee: posee una familia, posee bienes materiales, posee dignidad y cualidades y — sobre todo- posee sus derechos, 
plenamente- sólo conduce a la más extrema cosificación, no sólo del ser humano sino de la naturaleza y del universo todo. ${ }^{8}$ Frente a esta condición, Villoro hace una referencia cuasinostálgica a formas sociales y culturales premodernas, incluso precristianas, donde aquella enajenación y conciencia solitaria no se presenta, y donde los seres humanos viven todavía, como en el paganismo grecorromano, 9 "la unificación afectiva con el cosmos, la participación simpatética en él", ${ }^{10}$ la armonía con la naturaleza y la comunión entre sí mismos. Nada de esto subsistirá en la cultura de la modernidad, en la que se abandonará totalmente cualquier visión espiritual, cualitativa o afectiva del mundo natural. Ningún rastro quedará de aquella unidad primigenia, de aquella imagen orgánica, holística del ser y lo existente. La enajenación humana se cumplirá cabalmente.

Aunque la visión científica resulta la forma cultural más reconocida de la nueva concepción de la naturaleza - mecanicista y objetivista-, Villoro encuentra en el idealismo filosófico y el subjetivismo reflexivo (de Descartes a Kant) la fórmula más acabada de la visión egológica moderna. ${ }^{11}$ Contra esta visión, la rebelión antiidealista y antiintelectua-

sus sacrosantos derechos, intangibles porque son... 'propiedad privada'" (ibid., p. 117). La crítica al carácter "burgués" (egoísta, egocéntrico) de los "derechos" en general, y de los "derechos humanos" en particular, persistirá en el pensamiento de Villoro hasta sus reflexiones sobre los problemas de la interculturalidad. Cfr. L. Villoro, "Aproximaciones a una ética de la cultura", en Estado plural, pluralidad de culturas (1998), pp. 109-139 (particularmente las pp. 129-133, apartado sobre "Derechos humanos").

${ }^{8}$ En un texto posterior, que muestra la persistencia de esta preocupación, Villoro explica: "La destrucción de la naturaleza por la técnica obedecía a una actitud más profunda: la degradación de los entes naturales en meros objetos. Al reducir el mundo a un material que debe ser dominado y transformado, las cosas dejan de tener un sentido intrínseco, sólo adquieren el sentido que el sujeto humano les atribuye. El hombre deja entonces de escuchar lo que tengan que decirle las cosas, para exigir que se plieguen al lugar que les señala su discurso". (L. Villoro, El pensamiento moderno. Filosofía del Renacimiento (1992), p. 94).

${ }^{9} \mathrm{Y}$ también, como lo expone Villoro en otros textos, en las culturas no occidentales en general, en la cultura oriental, en las estudiadas por los antropólogos contemporáneos y, particularmente, en la cultura indígena americana.

${ }^{10}$ Villoro, "Soledad y comunión", p. 115.

${ }^{11} \mathrm{El}$ "yo trascendental" simboliza a la perfección la consagración del autoaislamiento del yo, su abstracción del mundo, y el correlativo vaciamiento de sentido de todo lo existente. "En el Yo trascendental la naturaleza, como realidad independiente con sentido propio, queda definitivamente rechazada; pues[to] que sólo es naturaleza aquello que el sujeto del conocimiento crea al dictarle sus propias leyes. Pero lo más grave es que el mismo sujeto personal, concreto, queda relegado fuera de la esfera del conocimiento objetivo. El sujeto del conocimiento científico es 
lista del existencialismo buscó, en principio, restaurar la realidad y la verdad del sujeto humano, el modo de su existencia concreta. De Kierkegaard a Sartre se lleva a cabo un proceso de reflexión que radicaliza, en lugar de simplemente negar o tratar de "superar", la experiencia dramática de la soledad existencial, de la finitud, del abandono y la contingencia humana. La revelación sartreana de que nuestra angustiada condición existencial es la otra cara de la conciencia de nuestra libertad más pura, de nuestra autosuficiencia o nuestra nada de ser, tiene para Villoro un carácter sólo provisional, pues, advierte, "detrás de cada acto plenamente libre vemos dibujarse una evanescente silueta: la soberbia. Más allá de la conciencia de la total autosuficiencia de mi acto, el orgullo satánico se dibuja siempre"12. La conciencia de nuestra libertad radical, si bien es una enseñanza irrenunciable del existencialismo sartreano, no anula sino que, por el contrario, agrava el drama de la soledad humana. Sólo en este momento, y más allá de Sartre, más allá del "en sí" pleno y compacto, descubro, en cuanto subjetividad concreta, "la fascinante presencia de una evanescente y extraña compañía": ${ }^{13}$ la del otro, la del tú; esa dimensión a la que sólo la senda filosófica de Gabriel Marcel nos sabe llevar de manera expresa. ¿Qué es el Otro? ¿Quién es el otro? ${ }^{14}$

Lo que ante todo valora Villoro de Marcel es la visión concreta y relacional, interpersonal, del "yo" de la tradición reflexiva de la filosofía moderna, que nos permite trascender efectivamente los cercos y los límites egológicos e intelectualistas del idealismo filosófico. Marcel considera la pregunta “¿qué soy yo?" como el punto de partida de

necesariamente impersonal. Es todos a la vez y nadie concretamente; es un sujeto anónimo y universal. El sujeto individual, el hombre de carne y hueso, resulta, ante aquel Yo trascendental, un objeto más de laboratorio" (Villoro, "Soledad y comunión", p. 118).

${ }^{12}$ Ibid., p. 120.

${ }^{13}$ Ibid., p. 122.

${ }^{14}$ Luis Villoro, "La reflexión sobre el ser en Gabriel Marcel", en Páginas filosóficas (1962). En este artículo podemos apreciar la comprensión que tiene Villoro del existencialismo, y percibir las razones que explican su interés por la postura del pensador francés. Algunas de esas razones perdurarán en su desarrollo filosófico hasta hoy día, aun cuando no la referencia ni la tematización directa de los autores trabajados en aquel entonces. Como veremos, el "existencialismo" de Villoro bien pronto se reconfigurará y canalizará a través de distintos desarrollos y preocupaciones que lo alejarán de los textos y los términos existencialistas, pero no del espíritu esencial, "existencial", de esta doctrina. De hecho, Villoro hará lo mismo con las diversas doctrinas filosóficas con las que entrará en contacto (fenomenología, filosofía analítica, marxismo, etc.): interpretarlas y reconstruirlas críticamente en función de una estrategia teórica propia. 
una reflexión metafísica radical. Pero pronto observa que la vía cartesiana, la del cogito, la reflexión y el pensamiento nos hace alejarnos totalmente de la experiencia y de la realidad, del Ser, para dejarnos en el ámbito de las puras representaciones, imposibilitados para retornar jamás a lo que existe. Para el sujeto pensante, el "objeto" es una idea —no un ser real, del cual se tiene una experiencia-; simultáneamente, el "sujeto" no es un ser existente, sino un ente puramente abstracto e irreal. La dicotomía "sujeto-objeto", en cuanto tal, vuelve inaccesible al Ser. El objeto es, si acaso, un "problema", esto es, algo que eventualmente podrá "resolverse", definirse y reintegrarse en el sistema de conceptos del pensamiento. Por el contrario, el Ser sólo podrá aparecer en el ámbito de lo metaproblemático, lo que Marcel llama - y es una de sus categorías fundamentales- el ámbito del "misterio"; es decir, de lo que no se puede "resolver", capturar, poseer (tener), y a lo que sólo podemos acceder mediante una participación vivida (en el ser). ${ }^{15}$ Así, la existencia vuelve a adquirir el carácter de trascendencia respecto del pensamiento. Esta trascendencia comienza operando con relación a nuestro propio "yo". Por detrás del ego cogito cartesiano - pura inmanencia, pura presencia de sí a sí-, Marcel descubre, a través de una reflexión secundaria (una reflexión de la reflexión), el yo existencial y concreto que se encuentra de principio abierto a algo que no es él —su situación, su corporalidad-, que no domina ni controla y de lo que no puede, por ende, anular su trascendencia. Es en la existencia donde el yo y el no-yo, la conciencia y el mundo, se confunden y participan uno de otro.

Así pues, Marcel no abjura del pensamiento, de la reflexión. No busca el retorno a un realismo empirista ni postula un intuicionismo de la identidad vacía (entre sujeto y objeto). Lo que propone es una distinción, un desdoblamiento. Existe, junto a la reflexión primera, intelectual, meramente epistemológica, una reflexión segunda, existencial y metafísica. Existen también dos modos del pensamiento: Denken, "pensar algo", y Andenken, "pensar en algo" o "acerca de algo". En el primero el objeto se encuentra enteramente bajo el dominio del pensamiento, y es, por eso, algo siempre determinado y definido. En el segundo, en cambio, no hay tal dominio ni determinación: "al pensar en alguien o acerca de algo - explica Villoro-, participamos en la cosa pensada, nos interiorizamos en ella". ${ }^{16}$ Aquí, el pensamiento nos lleva efectivamente a algo que no es pensamiento, a lo otro del pensamiento. ¿Cómo es esto

${ }^{15}$ La dualidad "tener-ser" constituye uno de los tópicos más conocidos de la reflexión de Marcel. Cfr. Gabriel Marcel, Ser y tener.

${ }^{16}$ L. Villoro, "La reflexión sobre el ser en Gabriel Marcel”, p. 173. 
posible? Sólo en el ámbito de la vida humana interpersonal, sólo en la relación con un otro humano, a través del tú. La comunión interpersonal es lo único que puede mantener al sujeto en "el terreno propio de la metafísica", en el terreno del Ser como tal. Pues, precisamente, el "otro" es lo que no se puede reducir a "objeto", a concepto o representación por y para el "yo" pensante; es lo que ante todo "existe", esto es, lo que sólo "es" a partir de un (su) modo propio e irreductible de ser.

Como puede apreciarse: motivo metafísico y motivo existencial —esto es, resguardo de la trascendencia del Ser frente al idealismo filosófico y, simultáneamente, reconocimiento de la alteridad radical del otro frente al egocentrismo humano- se integran y explican mutuamente en la reflexión filosófica de Marcel. Esta integración señala, a su vez, la propia motivación inicial del pensamiento de Villoro, que él mantendrá y desarrollará por su propia cuenta y por diversos e inéditos caminos. Una preocupación por el Ser — por lo real, por lo que existe- que encontrará en la relación con el otro su referente primario y su modelo; un interés por el otro — por el tú, por el excluido, por el olvidado- que no dejará de plantearse, en el marco de una reflexión sobre las condiciones mismas del pensamiento, de la razón y de la verdad. Sólo accedemos a lo otro (al Ser) a través del otro (del tú), pero sólo podemos sostener y mantener el acceso al otro humano en la apertura comprensora de lo otro en general.

La experiencia del otro es, por excelencia, la experiencia de una trascendencia irreductible, desarrolla Villoro. En esto consiste el carácter propio y específico de la otredad: en que no se puede determinar ni definir y de lo que sólo podemos hablar adecuadamente en términos negativos: "lo que no es tal o cual". Surge así la paradoja de un ser - el otro- cuyo aparecer es su "no aparecer". Los actos y discursos del otro "no concuerdan exactamente con las motivaciones que yo les había prestado y con los cuales había creído poder determinarlo". ${ }^{17}$ No sólo constato que el otro rebasa todas mis determinaciones, que no puedo controlar ni definir sus expresiones y manifestaciones, sus gestos y todas las maneras como se muestra ante mí; constato, aún más, que todo lo que él es y expresa proviene de él mismo. "El tú —explica Villoronada tiene en su ser que tan sólo provenga de mí. Es una fuente propia de valor y sentido, irreductible a mi yo"18. Es, realmente, otro distinto de mí, otro ser ante mí o, más exactamente, conmigo, junto a mí.

\footnotetext{
${ }^{17}$ Villoro, "Soledad y comunión", p. 124.

${ }^{18}$ Ibid., p. 127.
} 
¿Pero cómo podemos acceder al otro, cuando la vía intelectual reduce inexorablemente el otro al sí mismo, a sus supuestos, concepciones y propósitos? Hay una forma de experiencia emocional que, sin embargo, guarda todavía cierto sentido cognitivo: se trata de la "fascinación". Más que un tipo de acto o de actividad, la fascinación es una experiencia "pasiva" — experiencia de descentramiento, de apertura, de anonadamiento-. Consiste, define Villoro, en "el paradójico sentimiento de atracción mezclada con temerosa inquietud. Nos fascina siempre lo oculto, lo que se presenta pero no puede captarse plenamente, lo que sólo está indicado y señalado, lo que se emboza y disfraza, lo que se deja presentir sin ponerse nunca a nuestro alcance" ${ }^{19}$ Lo fascinante es lo "irrevelado irrevelable": no es simplemente algo que no se revela, sino algo que se revela en cuanto "no revelable", en cuanto misterio inabarcable, en cuanto trascendencia irreductible. Es lo inconceptualizable, lo inapresable, lo incapturable. Es como la oscuridad, que solamente podemos captarla en cuanto tal si evitamos alumbrarla (pues entonces deja de ser oscuridad). La fascinación es la posibilidad de "salir de sí", de "abrirse" desde lo más profundo y completo de sí mismo al otro.

Ahora bien, la vía de la fascinación nos permite reconocer el misterio del otro, su alteridad; pero no nos ofrece todavía la forma de un acercamiento y una comprensión reales. Su valor reside, en todo caso, en que nos permite transitar hacia un temple de ánimo donde empezará a ser posible superar la desintegración, el desfase. Se trata de la pasión "como acción transida de amor o como amor explayándose en acción", como "acción amorosa" o "amor activo". Sólo el sentimiento del amor permite el acceso al otro en cuanto otro-ser, en cuanto ser-otro, asume Villoro. Más allá de la reflexión, más allá del pensamiento "identificador", siempre egocéntrico, la única vía para acceder al otro es la del amor: la capacidad de afirmar el ser del otro sobre el ser del sí mismo (nada que ver con el concepto posesivo del amor, que es falso amor y falsa entrega: dilatada y truculenta afirmación del sí mismo).

No obstante, aclara Villoro, la relación amorosa con el otro jamás puede consumarse de forma total, pues entonces se agotaría la trascendencia que lo define, se anularía su alteridad propia. El encuentro amoroso con el otro no supera ni cancela la soledad original del yo. La hace más llevadera o, en todo caso, amplía Villoro, hace de la ansiada comunión humana un deseo abierto, funda la esperanza en una unificación absoluta pues, sentencia, "sólo en el infinito puede la existencia afirmar la Trascendencia Absoluta, como término final de su amor y de

${ }^{19}$ Villoro, "Raíz del indigenismo en México" (1952), pp. 43-44. 
su fe". ${ }^{20}$ Surge, así, en el horizonte de la dialéctica irresoluble de la condición humana - autosuficiencia y dependencia, afirmación del sí mismo y entrega amorosa al otro-, el sentido de lo "sagrado", el horizonte ideal de la comunión universal. Queda abierto un nuevo estadio de la otredad —el Otro, lo Otro absoluto— que hemos de retomar más adelante.

\section{La alteridad cultural: el otro humano, el indígena}

Más allá del existencialismo, más allá de los límites de toda filosofía personalista, Villoro vislumbra una experiencia de la otredad para la cual la filosofía occidental cuenta en general con pocos recursos. Se trata de la experiencia del Otro en cuanto perteneciente a otro mundo histórico-cultural, a otra cultura. No se trata solamente de la experiencia del otro-yo, con quien de alguna manera comparto ciertos elementos y rasgos socioculturales —el lenguaje, por ejemplo- que finalmente permitirán superar, aunque sea relativamente, mi inherente egoísmo egocéntrico. ${ }^{21}$ En el plano intercultural, el otro se presenta no sólo como un ser otro, distinto, diferente, sino aún más, como un ser extraño, incomprensible, anómalo y, llevado al límite, como un ser negativo, como la representación del mal, o al menos como poseedor de una realidad menor, secundaria o problemática. $^{22}$

Es el ser del otro, del indígena americano, tal y como apareció para los conquistadores europeos ${ }^{23}$ y tal como, en el caso de nuestro país, ha subsistido desde entonces para la conciencia nacional. De ahí que

${ }^{20}$ Villoro, "Soledad y comunión”, p. 131.

${ }^{21}$ Dussel ha observado que, para pensar el sentido de la otredad desde la condición del colonizado americano, es necesario ir más allá de Lévinas, en cuyo pensamiento una perspectiva crítica con parámetros geopolíticos —esto es, anticolonialista - no está planteada de forma sistemática y directa. La filosofía de la otredad de Villoro coincide con esta observación. Su reflexión sobre la problemática indígena en México muestra un límite de la políticamente abstracta visión levinasiana de la otredad. Cfr. Emmanuel Lévinas, Totalidad e infinito.

${ }^{22}$ Una filosofía sistemática de la otredad debería incluir, entre la otredad interpersonal y la otredad intercultural, la otredad de género, la diferencia de los sexos o la alteridad femenina. Los caracteres con los que se cualifica y determina al miembro de otra cultura se encuentran ya presentes en la forma históricamente dominante en que se ha concebido y definido a la mujer: sujeto verdaderamente "diferente" en una relación interpersonal (no "un-otro", sino "una-otra"). La filosofía feminista, ampliamente desarrollada en las últimas décadas, está presentando tesis que de hecho implican el replanteamiento de las filosofías de la otredad elaboradas hasta ahora. Cfr. entre otras autoras, Geneviève Fraisse, La diferencia de los sexos.

${ }^{23}$ El caso histórico paradigmático e incomparable de "encuentro con el otro" 
el segundo nivel de una filosofía de la otredad solamente podrá ser pensado en toda su originalidad y particularidad desde una reflexión filosófica periférica a las metrópolis occidentales, que fueron a la vez las potencias coloniales del mundo moderno. Desde esta perspectiva, la "egología" se aparece no solamente como un rasgo intelectual característico de cierta época de la filosofía occidental, en realidad constituye un rasgo (quizá el rasgo) cultural y sociopolítico propio de Occidente. La condición de la colonización - de la dominación- es precisamente una inicial "negación" del otro o, más exactamente, su constitución discursivo-ideológica como "objeto" de dominio y control. ${ }^{24}$

La colonización consistió en un proceso de desconocimiento y negación del otro, del indígena, mediante un mecanismo de construcción y definición de su ser desde los marcos ideológicos y las estrategias políticas del colonizador y sus sucedáneos. Villoro propone afrontar el problema de la alteridad indígena en México a través de una genealogía de los modos en que esa alteridad ha sido negada y reconstruida a lo largo de la historia de nuestro país. Su análisis (que lleva cabo en el libro Los grandes momentos del indigenismo en México (1950)) busca responder a varias inquietudes. En primer lugar, se plantea poner las bases para un entendimiento adecuado de la condición nacional y para acercarnos a la resolución de nuestros más graves problemas (el análisis da cuenta a la vez de las concepciones y posiciones de los diversos sectores sociales que han conformado históricamente a nuestro país). Busca también ahondar en una reflexión sobre la otredad de gran caladura histórico-antropológica, y concomitantemente se propone, aun sea indirectamente, mostrar los límites, quizá la incapacidad congénita, de las principales fórmulas del pensamiento occidental — cristianismo, racionalismo, romanticismo, positivismo, nacionalismo, marxismo- para comprender adecuadamente al indígena (al otro en general). Un distanciamiento crítico respecto de la "filosofía occidental" permanecerá como una especie de leitmotiv secreto o discreto en la trayectoria filosófica de Villoro (lo que explica su interés por la filosofía oriental, por el sentido primigenio del cristianismo, por la idea de "sabiduría" y, particularmente, por los valores simbólicos de las culturas indígenas de México).

La estrategia de constitución ideológico-discursiva del indígena -la definición de su "ser", esto es, el "indigenismo"25 — es algo más que un

sigue siendo el del descubrimiento y posterior conquista de América. Cfr. Tzvetan Todorov, La conquista de América. El problema del otro.

${ }^{24}$ Cfr. Enrique Dussel, 1492. El encubrimiento del Otro.

${ }^{25}$ Debe tenerse en cuenta siempre la definición de Villoro del "indigenismo" como 
procedimiento intelectual o teórico. Se trata, ante todo, de un mecanismo que busca alcanzar efectos prácticos, reales: la constitución del indígena conlleva procedimientos materiales (técnicos, económicos, jurídicos, religiosos) que realizan su dominación en cuanto grupo social y en cuanto mundo cultural distinto. ${ }^{26}$ Independientemente del carácter subjetivo y parcial de la valoración que hace el no-indígena del indígena, la definición discursiva del lugar del indígena implica de suyo un mecanismo de falsificación, de suplantación; conforma un dispositivo para la dominación, la exclusión o la negación. ${ }^{27}$

En todos sus momentos, el discurso indigenista - desde el conquistador cristiano hasta el mestizo nacionalista, pasando por el criollo

un discurso hecho por no indígenas acerca de lo indígena. Cfr. Villoro, "De la función simbólica del mundo indígena”, pp. 429 y ss.

${ }^{26}$ Resulta interesante, desde este punto de vista, precisar los componentes o mecanismos de toda estrategia de constitución ideológico-discursiva del indígena que Villoro enumera: 1) el "sujeto" de la estrategia, que en este caso es un sujeto étnicosocial (y la ideología en que se sustenta): ya el conquistador español, el criollo novohispano o el mestizo "mexicano", que corresponden a sendas épocas en la historia del país y definen los "tres grandes" momentos del indigenismo en México; 2) el tipo de "valoración" que se hace del indígena (negativa, relativamente negativa, positiva, etc.) y que establece la pauta para su definición y para la delimitación del tipo de relación que se debe tener con él y el tipo de acciones político-sociales que deben efectuarse con respecto a su situación; 3) el "lugar" espacio-temporal en que se ubica al indígena: cercano, lejano, inaccesible; en el pasado, el presente o el futuro Este último mecanismo determina la naturaleza estratégico-política de las posturas indigenistas. El "lugar" en que se ubica al indígena es elegido, decidido, por el discurso indigenista; implica un proceso de "abstracción" mediante el cual se separa al indígena de su ser real y su lugar concreto para "ubicarlo" en un lugar irreal, artificial, definido discursivamente por el indigenista (véase el cuadro de la página 239 de L. Villoro, Los grandes momentos del indigenismo en México, (1950)).

${ }^{27}$ De acuerdo con lo anterior Villoro define tres posibilidades, y tres épocas histórico-culturales correspondientes, de la manera como se ha pensado, construido, "falsificado", al ser del indígena: 1) ubicado en un lugar cercano y presente, pero valorado de forma totalmente negativa - un ser "demoníaco" que si acaso hay que "convertir" a la nueva fe- la época de la conquista, en el horizonte de la concepción ideológica cristiano-occidental del europeo o peninsular; 2) valorado de forma positiva pero situado en un lugar lejano y como realidad "pasada": la mistificación nacionalista de las grandes culturas indígenas prehispánicas, que comienza desde las postrimerías de la Colonia y se asienta en el México independiente, bajo la perspectiva racionalista moderna del criollo (el humanismo de Clavijero, la mistificación romántica de fray Servando Teresa de Mier, o el positivismo histórico aséptico de Manuel Orozco); y 3) ubicado en el presente y/o proyectado al futuro, valorado de forma totalmente positiva, aunque como realidad enigmática y trascendente: la época posrevolucionaria bajo la perspectiva del indigenismo nacionalista o socialista mestizo. Cfr. Villoro, Los grandes momentos del indigenismo en México. 
independentista- se desenvuelve ineludiblemente en los marcos del pensamiento "occidental", en cuanto pensamiento "subjetivo", objetivador e intelectualista. ${ }^{28}$ Esto es, una forma de pensar, histórico-culturalmente conformada, que pone siempre como centro de toda experiencia y de toda relación con el mundo al "ego", el Yo o el Sí mismo. De ahí el fracaso por principio de la relación con el otro, de la relación del noindígena con el indígena. El esquema occidental sujeto-objeto - ya en la fórmula religiosa, ya en la fórmula racionalista moderna, ya, incluso, en la fórmula del indigenismo revolucionario y solidario- conlleva de suyo una relación de exterioridad, de distancia y finalmente de dominación. El otro está condenado a ser un "objeto" para el "yo"; siempre "es" lo que el "yo" define, capta, interpreta y quiere de él; no hay posibilidad de inversión de los papeles, de intercambio y de reciprocidad entre ambos polos. Por esto, además, la aprehensión del otro siempre conduce a un desconocimiento o a una falsificación. El sujeto no se detiene en la realidad y en la experiencia efectiva del ser del otro; pronto limita esta experiencia y remite los datos que tiene ante sí a los marcos de una teoría previa, de una concepción preestablecida. Independientemente de las diferencias entre las distintas concepciones occidentales, todas ellas padecen un mismo defecto que resulta consustancial al pensamiento occidental: su incapacidad para abrirse a lo concreto de la experiencia humana, a la situación real, en toda su complejidad, ambigüedad y problematicidad. Su incapacidad para rebasar el cerco del pensar que opera en todo momento según el principio de la identidad.

De esta manera, la condición para alcanzar una conciencia adecuada del mundo parece estar, para Villoro, en saber rebasar el nivel puramente intelectual, reflexivo, teórico o ideológico del pensamiento; esto es, en saber complementar el conocimiento (y la acción que éste funda) con la experiencia, con la relación vivida con el mundo y la apertura emocional al otro. Se trata de arribar al nivel de una "conciencia existencial", vital y concreta. Sólo reconociendo que el intelecto tiene límites, que nuestro saber nunca puede ser total y acabado, estamos en condiciones de acceder efectivamente a la alteridad, de entrar en contacto verdaderamente con el otro. No se trata, ciertamente, de efectuar una negación absoluta, irracional del "sí mismo" — de un puro autosacrificio-, sino de obrar una negación relativa, una "puesta en suspenso" de nuestro inherente principio de egoidad, para abrirnos íntimamente al otro y, así, llegar a comprenderlo verdaderamente. Se

${ }^{28}$ Sobre la caracterización de esta forma de pensamiento y sus efectos en la colonización de América, cfr. Eduardo Subirats, El continente vacío. 
trata, pues, de poner en práctica también aquí la vía del "amor", o más exactamente, la combinación de una acción comprometida con el otro y de un amor que sabe reconocer, valorar y mantener su "diferencia". Sólo en la unión de acción y amor podrá lograrse una aproximación al otro, al indígena, que no lo destruya ni se quede indiferente ante él. Dice Villoro:

sólo la caridad activa, sólo la acción amorosa podrá recuperar el ser indígena sin esclavizarlo a nuestros proyectos ni dejarlo tampoco en el alejamiento y el abandono. Porque aquella esfera que la reflexión no puede iluminar, aquella que la fascinación sólo señala sin revelar plenamente, sólo la pasión puede alcanzar; que ahí donde la reflexión fracasa, acción y amor logran su objeto. ${ }^{29}$

A pesar de todo, el límite infranqueable de toda conciencia indigenista es, finalmente, que el indígena aparezca siempre y necesariamente como instancia "revelada", y nunca como instancia "revelante". La reciprocidad de las miradas, del reconocimiento, está excluida aquí. Como dice Villoro, "hablamos del indio, lo medimos y juzgamos, pero no nos sentimos ni medidos ni juzgados por él" ${ }^{30}$ El indígena aparece en todos los casos como un "objeto" para, o ante la mirada, el juicio o la decisión de otro. Sea que se le oponga, sea que le convenga, para sojuzgarlo, para utilizarlo, o bien para liberarlo, ${ }^{31}$ es siempre otro y no el indígena quien toma la iniciativa. En el encuentro que tenemos con el indígena, por más que busquemos iluminarlo con nuestras categorías y actitudes, permanece "un sentido personal, desconocido y no realizado en la superficie que muestra ante nosotros: su capacidad de trascendencia", ${ }^{32}$ esto es, su alteridad, su ser Otro. Es la voz, la autorrevelación propia del indígena lo que aquí falta todavía. Villoro tendrá que esperar más de cuarenta años para ver aparecer el último "gran momento", ya no del "indigenismo", sino de aquello que las páginas finales de su libro anuncian: la necesidad y posibilidad de una conciencia indígena autónoma, de un movimiento indígena (el "neozapatismo") que habla desde sí mismo y por sí mismo, e interpela desde ahí a la nación entera para saldar cuentas pendientes y, sobre todo, para reconstituir las bases del proyecto de país que también debemos. El significado de

\footnotetext{
${ }^{29}$ Luis Villoro, "Raíz del indigenismo en México", pp. 48-49.

${ }^{30}$ Luis Villoro, Los grandes momentos del indigenismo en México, p. 240.

31 "Uno no libera al otro dotándolo de una esencia única aunque sea prestigiosa; así uno se libera de él" (Alain Finkielkraut, La sabiduría del amor, p. 32).

${ }^{32}$ Villoro, Los grandes momentos del indigenismo, p. 243.
} 
este "cuarto momento" lo retomará Villoro, ya no en la perspectiva de un análisis histórico de la conciencia mexicana, sino en el proyecto filosóficamente fundamental de una "filosofía política" para el mundo contemporáneo.

\section{La alteridad metafísica: el Otro absoluto, lo sagrado}

Como un intermezzo, o bien como una especie de punto de fuga, de apertura radical, aparece la reflexión villoriana sobre la experiencia religiosa. Aunque no es una temática central ni ampliamente expuesta, consideramos que la reflexión metafísico-teológica de Villoro ofrece claves importantes para entender cabalmente el sentido de su filosofía de la otredad (personal, cultural y política) y el talante último de su concepción y actitud filosóficas, su asunción de la filosofía como una sabiduría de los límites.

Probablemente el texto más "escandaloso" de los que ha escrito Villoro sobre la experiencia religiosa es aquel donde dialoga con una de las figuras filosóficas más reconocidas y oficiosamente definidas del siglo xx: Ludwig Wittgenstein. En el trasfondo de las aportaciones y las discusiones sobre lógica, epistemología y filosofía del lenguaje, Villoro se comunica con un Wittgenstein poco visitado: el de las escuetas y discutidas observaciones sobre metafísica, ética, estética y teología: todo aquello de lo que sería "mejor callarse". En "Lo indecible en el Tractatus" (1975), Villoro retoma la paradójica afirmación de Wittgenstein de que "la parte no escrita" de su Tractatus logico-philosophicus "es la que es importante", ${ }^{33}$ aquella que trata de "lo que no puede decirse en él y sólo se comunica después de haber comprendido que no puede decirse". ${ }^{34}$ Estamos en los límites de la "paradoja", algo que hace de Wittgenstein un gran pensador (como Heráclito, Kierkegaard, Nietzsche, Heidegger). Como es sabido, el objeto explícito del Tractatus es establecer los límites del lenguaje con sentido (proposiciones que figuran hechos), que son a la vez los límites del mundo (la totalidad de los hechos). Ahora bien, este propósito, en cuanto tal, implica rebasar las propias condiciones y los límites propuestos, pues sólo puede realizarse mediante proposiciones (pseudoproposiciones) que violan las reglas planteadas, que carecen, pues, de sentido. Si bien Bertrand Russell lo decía irónicamente, es cierto que, para definir con claridad aquello "de

\footnotetext{
${ }^{33}$ Villoro, "Lo indecible en el Tractatus", p. 6.

${ }^{34}$ Ibid, p. 7.
} 
lo que sí se puede hablar", Wittgenstein se las tiene que ingeniar para definir aquello "de lo que no se puede hablar". ${ }^{35}$

Aunque sólo en algunas breves líneas (entradas) del final del Tractatus se ocupa Wittgenstein de lo "indecible", toda la obra apunta en realidad a ello, en cuanto que, como subraya Villoro, lo indecible es condición de lo decible. Así, los objetos son condición de un lenguaje figurativo con sentido, pero los objetos mismos no pueden ser figurados en cuanto tales, son indecibles. Igual sucede con la forma lógica -lo que tienen en común la proposición con el hecho-: es una condición a priori del lenguaje figurativo, pero ella sólo puede "mostrarse" en lo decible, tampoco puede "decirse" directamente. Finalmente, la existencia del mundo allí, el que el mundo sea, es una condición también indecible del lenguaje y de la lógica, que sólo pueden hablar de cómo es el mundo. Por esto, para Wittgenstein, la experiencia básica de que el mundo es pertenece a lo "místico" (entrada 6.44 del Tractatus).

Atenidos a la lógica y al lenguaje, el mundo se aparece como un "todo limitado" (por el espacio lógico); esto es, como la "totalidad de los hechos"; por ende, como algo "absolutamente contingente" 36 (que puede ser de un modo u otro, o puede simplemente no ser) y totalmente independiente de mi voluntad y de mis juicios de valor; éstos están "fuera" del mundo, y al igual que el "todo" del mundo (lo que está "dentro") no puede ser objeto de ninguna representación o discurso: sólo puede ser producto de una "visión", de un "sentimiento". "El sentimiento del mundo como un todo limitado es lo místico", repite Wittgenstein (Tractatus, 6.45).

No es casual —explica Villoro- que Wittgenstein emplee la palabra "místico". La consideración del mundo como un acontecimiento inexplicable, gratuito, que hubiera podido no ser y, sin embargo, es, causa un indescriptible asombro. Ahí está el mundo, como un milagro brotado de la nada. En lugar del vacío infinito, la presencia inefable del universo. No es sólo la perplejidad de la razón ante lo incomprensible para ella, es un sentimiento de pasmo, de estupor, ante lo extraño por excelencia: lo otro, la presencia misma del mundo. ${ }^{37}$

Lo absolutamente otro no tiene, en principio - para Wittgenstein y para Villoro-, ninguna determinación; no es ninguna clase de entidad,

35 "Introducción” de B. Russel a L. Wittgenstein, Tractatus logico-philosophicus, p. 27.

${ }^{36}$ Villoro, "Lo indecible en el Tractatus", p. 11.

${ }^{37}$ Ibid., p. 12. 
mundana o supramundana. La raíz de toda experiencia religiosa, mística, "el portento puro y simple no es tal o cual hecho que acontezca en el mundo, sino la existencia inexplicable del mundo". ${ }^{38}$ La experiencia de esta otredad inefable, de este misterio tremendo y fascinante (Rudolf Otto) ${ }^{39}$ que escapa al discurso, pero que a la vez lo hace posible, no es nada especial y extraordinario: consiste simplemente en ver al mundo "en su pura existencia fáctica", ${ }^{40}$ en su pura y silenciosa presencia.

Ahora bien, aunque esa experiencia no puede ser dicha, sí puede ser "comunicada" por el lenguaje: de manera negativa, indirecta. Al decir que lo místico, lo sagrado, no es ningún hecho del mundo o del ultramundo, estamos comunicando que no puede tener una forma determinada pero no lo estamos anulando o negando de manera absoluta. Las pseudoproposiciones con las que lo mencionamos no son un puro sinsentido en el sentido de la lógica; ${ }^{41}$ se trata, propone Villoro, de una segunda clase o nivel de sinsentido: el que intenta decir algo que sólo se muestra; intento que necesariamente fracasa pero que, en este fracaso, algo se acerca a su objetivo: indicar hacia aquello que hay que "ver" por sí mismo, trasponernos más allá de los "límites" del mundo y del lenguaje.

La metafísica (y la ética, la estética, la religión, etc.) no es eliminada sino desplazada y corregida. Nos liberamos de la ilusión tradicional que quiere encontrar los referentes de la metafísica y la ética en el mundo que es representable por el lenguaje. El "sentido de la vida" no se encuentra en ningún acontecimiento, fenómeno o hecho del mundo; no se encuentra en ningún lado, es decir, se encuentra, simplemente, en el todo de la vida, en la vida misma; "el sentido de la vida es vivirla en plenitud": interpreta Villoro. Igual lo divino, lo sagrado. "Dios no es algo distinto del mundo o de la vida sino el sentido mismo de ambos." 42 No es algo que podamos captar con el pensamiento y la representación (discursiva, cognoscitiva, científica), y no entenderemos lo que significa, lo que "es", si no asumimos rigurosamente los límites del lenguaje y

38 "Muchos milagros hay en el mundo — dice San Agustín— pero 'el mayor milagro de todos es el mundo mismo" (ibid.).

${ }^{39} \mathrm{Cfr}$. los textos ya clásicos de la reflexión filosófico-antropológica del siglo $\mathrm{XX}$ sobre lo "sagrado", presentes en la visión de Villoro: Rudolf Otto, Lo santo. Lo racional y lo irracional en la idea de Dios; Mircea Eliade, Lo sagrado y lo profano; G. van der Leeuw, Fenomenología de la religión.

${ }^{40}$ Villoro, "Lo indecible en el Tractatus", p. 15.

${ }^{41}$ Son proposiciones que violan las reglas particulares de la lógica y que pretenden decir lo que no puede decirse ni mostrarse; por ejemplo: "el número 3 es amarillo".

${ }^{42}$ Villoro, ibid., p. 34.

Diánoia, vol. LII, no. 58 (mayo 2007). 
de la lógica. Seguiremos confundiendo entonces lo sagrado (el sentido, el valor) con "algo" (que no es ni puede ser) y seremos incapaces de comprenderlo correctamente, adecuadamente. Seguiremos ladeando la única e irrebatible experiencia de lo sagrado que tenemos: el sentimiento de todo del mundo y de la vida en cuanto tales. Nada más y nada menos.

La concepción de lo sagrado que Villoro destila de las observaciones de Wittgenstein precisa y recapitula rasgos fundamentales no sólo de su reflexión sobre la experiencia religiosa sino de su misma concepción y actitud filosóficas. Villoro no solamente otorga un sentido "mundano", inmanente, a lo sagrado - lo desmitifica, los desfetichiza, digamos: lo "desideologiza"-, sino que a la vez otorga un sentido "sagrado" a la existencia, al mundo como tal: lo que nos rebasa siempre, ya porque nos movamos en el plano de lo decible (de la lógica y la ciencia), ya porque nos movamos en el plano de nuestros intereses y deseos meramente egocéntricos. La experiencia de lo sagrado es la experiencia de un descentramiento radical. El sentido, el valor, lo divino, pero también el Ser, el mundo, lo existente, sólo pueden aparecer cuando ponemos "en suspenso" (en epojé) las determinaciones y delimitaciones de nuestra conciencia. Cuando ponemos en suspenso nuestro hablar, decir y definir, y sabemos escuchar entonces el sentido, las voces del silencio. ${ }^{43}$

Ahora bien, ${ }^{44}$ el "ser" que el silencio nos hace patente no es "esto ni lo otro", no es ninguna cosa definible, ningún hecho identificable, inmovilizado; no es plenitud, sino abismo. Es, en verdad, un puro "no ser" continuo, inasible e incontrolable. Una "nada" de ser. Ya lo busquemos del lado del mundo externo, ya del lado del mundo interno (del "yo"). Tal es la enseñanza metafísica última, insuperable. Aquella que nos legó de una vez y para siempre la filosofía oriental, la filosofía de la India. "Detrás del mundo manifiesto de la forma y la armonía —explica Villoro-, detrás del cosmos racional que la palabra determina, quiso el indio alcanzar el fondo oscuro sobre el cual toda forma se dibuja y toda

${ }^{43}$ Cfr. Luis Villoro, "La significación del silencio", en Páginas filosóficas (1962), pp. 33-60. Para un seguimiento del tema, véase: Isabel Cabrera, "La experiencia del silencio".

${ }^{44}$ ¿Es la experiencia metafísico-teológica de lo "absolutamente otro" fundamento o condición de posibilidad de la objetividad y verdad, de la base real, de nuestro conocimiento y nuestra racionalidad? Al menos desde el punto de vista "biográfico", Villoro recorre ese camino. Aquí sólo mostramos sucintamente lo que implica el pasaje de un momento a otro (de una "metafísica negativa" a una "epistemología crítica"). 
palabra se destaca. Y ese fondo es quietud, vacío, silencio." ${ }^{45}$ Brahma y Atman.

La cita anterior proviene de un breve artículo de 1959 donde el filósofo mexicano abrió el espacio para una reflexión y recuperación de una tradición de pensamiento totalmente distinta de la occidental. No se trataba solamente de un ejercicio de erudición cultural o de gusto por el exotismo. En realidad, Villoro se encuentra, por lo menos en un nivel personal y emotivo, más cercano a la manera de pensar oriental, con su sentido de la finitud, de la carencia y del vacío, que a la manera occidental y su obsesión por la plenitud, el ser, la presencia, el dominio... En este "viaje" imaginario hacia lo otro de Occidente que Villoro emprendió una vez, convergen los tres sentidos de la otredad que hemos comentado: el encuentro con el otro humano, el encuentro con la otra cultura (la del otro lado del mundo) y el encuentro con lo absolutamente Otro (la expresión humana más inasible y pura de lo sagrado). La sabiduría filosófica recobra aquí, para Villoro, su arcaico sentido de búsqueda, de aventura, de viaje a los confines.

La vía del silencio, del "sinsentido", ${ }^{46}$ que permite la revelación del otro y de lo otro, del ser, de lo sagrado, del mundo tal cual, no es para Villoro una vía positiva y directa, natural y espontánea. Implica un esfuerzo denodado, un reto y una aventura. Tiene implicaciones "críticas", consecuencias y efectos para nuestro pensamiento, nuestra comprensión y nuestra vida práctica. En primer lugar, tal vía implica una crítica del "sentido", esto es, del orden acabado de las significaciones establecidas, de la totalidad compacta e inmóvil de ideas y creencias que nos cierran a un orden mundano hecho e incuestionable. Este orden es el reino de la "actitud natural", de la vida irreflexiva, mecánicamente desplegada, donde vivimos sumidos y dominados más por el "falso saber" (el prejuicio) que por la "ausencia de saber" (la ignorancia). ${ }^{47}$

Ahora bien, cuestionar y superar este falso saber exige y requiere el

${ }^{45}$ Luis Villoro, "Una filosofía del silencio: la filosofía de la India”, en Páginas filosóficas, p. 110.

46 "Sentido y sin sentido son modos distintos en que el ser se hace presente. Por el primero, se revela en qué consisten los entes, su esencia; cada ente se abre a los otros y todos expándense en un mundo. Por el segundo, muéstrase el simple estar ahí de cada ente, su mera existencia; cada cosa persiste cerrada en sí misma; no hay mundo, tan sólo suma de existencias repetidas" (Luis Villoro, "El hombre y el sentido", en Páginas filosóficas, p. 30).

${ }^{47}$ Cfr. Luis Villoro, "Motivos y justificación de la actitud filosófica", en Páginas filosóficas, pp. 73-94.

Diánoia, vol. LII, no. 58 (mayo 2007). 
ejercicio de la razón. Sólo ella puede ayudarnos a distinguir entre las ideas falsas y las ideas verdaderas, sólo ella nos proporciona el criterio para esta distinción. ${ }^{48}$ La razón responde así, para Villoro, a un interés y a una necesidad humana fundamental: de purificación, de emancipación, de liberación. Liberándonos del falso saber y encaminándonos por el camino de la verdad y la objetividad, la razón nos ayuda a superar nuestros prejuicios y ataduras ideológicas, todo eso que nos impide salir de nosotros mismos - de nuestras representaciones y significaciones rígidamente asentadas - y reencontrarnos con lo que "es", con lo que "existe", con lo otro de nuestra conciencia. La razón crítica, por otra parte, también nos permite dirimir la "funcionalidad" del falso saber, de la ideología: la legitimación y el reforzamiento de la dominación, de las estructuras de poder que mantienen a los individuos sometidos, reducidos y encarrilados, aislados y enfrentados entre sí. ${ }^{49}$ La vía del conocimiento es pues, para Villoro, una vía de autognosis, de liberación. Una senda para el encuentro con el mundo, con los otros, con nosotros mismos.

En este sentido debe ser interpretada, creemos, la importante y elaborada teoría del conocimiento de Villoro. Más que una "teoría" de las facultades cognoscitivas, se trata de la descripción del proceso (de la fenomenología del espíritu en el sentido de Hegel) a través del cual nuestra mente transita del estadio inmediato e irreflexivo del conocimiento ("creer") al estadio del saber objetivo, formal y válido ("saber"), para arribar finalmente al estadio de la sabiduría, del conocimiento vital, práctico y concreto ("conocer"). Proceso que puede analogarse con la tríada hegeliana (el espíritu subjetivo, el espíritu objetivo y el espíritu absoluto), o bien, de estirpe más clásica y donde el sentido ético sobredetermina más claramente al proceso cognitivo, con los "géneros del conocimiento" de Baruch de Spinoza (imaginación, razón e intuición intelectual)..$^{50}$ Esa sobredeterminación da cuenta de cómo en Spinoza - $\mathrm{y}$ creemos que también en Villoro- los estadios del conocimiento constituyen a la vez o están vinculados a determinadas formaciones so-

${ }^{48}$ Que el punto de partida del conocimiento no es tanto un estadio natural de "no saber" (de ignorancia), sino más bien de "falso saber" (de creencias infundadas), proporciona ineludiblemente la justificación de la vía metódico-reflexiva de la filosofía moderna, tal y como fueron definidas sus bases por Descartes. Cfr. Luis Villoro, La idea y el ente en la filosofía de Descartes (1965).

${ }^{49}$ Cfr. Luis Villoro, El concepto de ideología y otros ensayos (1985a).

${ }^{50} \mathrm{Cfr}$. B. De Spinoza, La reforma del entendimiento. Sobre la convergencia en Spinoza entre los "grados del conocimiento", las formas de organización social y la programas prácticos, cfr. Gilles Deleuze, Spinoza: filosofía práctica. 
ciopolíticas y determinados programas prácticos. El estadio de la creencia está vinculado al dominio de la ideología y a las estructuras políticas que buscan imponer el "orden"; el estadio del saber, al dominio de la racionalidad formal, general, y corresponde a las estructuras políticas que ponderan el principio de la "libertad"; y el estadio del conocer, que se vincula con la racionalidad práctica y prudencial, y apunta el orden político (transpolítico, en realidad) de la "comunidad", de la democracia radical. ${ }^{51}$

\section{La alteridad socio-política: los otros, la comunidad humana}

En la búsqueda de la "comunidad" humana, la vía de la razón y la vía del sentimiento (del amor) se unen. También el dualismo de lo mismo y lo otro, de la identidad y la alteridad, se rompe y se abre al reconocimiento recíproco: el mundo de los otros, con los otros, el reino de la constitutiva pluralidad humana. La otredad deja de decirse en "singular" y se dice ahora en "plural". Implica un cambio fundamental en la perspectiva teórica. Transitamos de una visión existencial y metafísica a una visión epistemológica y ético-política, esto es, de una comprensión especulativa de la condición humana a una comprensión esencialmente práctica, dirigida por el propósito de construir, de hacer posible, nuevas formas de vida y nuevas formas de organización social. El otro ya no es aquel que me trasciende o enfrenta desde su distancia; el otro es, ahora, aquel con quien he de buscar, con quien hemos de buscar juntos, con-vivir, acordar, actuar en el mundo, formar comunidad.

Villoro nos recuerda que más allá de la función teórico-crítica, de reforma y corrección del entendimiento, la filosofía tiene y ha tenido siempre una preocupación y una orientación práctico-concreta, dirigida a la "búsqueda de la 'vida buena'". ${ }^{52}$ Planteada no sólo en términos personales, sino también colectivos o sociales, esta búsqueda lleva a la filosofía a una posición más o menos disruptiva del orden social existente, de las estructuras de dominación establecidas, y a la proyección

${ }^{51}$ Establecemos una correlación entre dos tríadas, la de las formas del conocimiento (creer, saber, conocer) y sus respectivas figuras socioculturales (ideología, ciencia y sabiduría), tal y como se exponen en Creer, saber, conocer (1982), y la tríada de los tipos de asociación política: asociación para el orden, asociación para la libertad y asociación para la comunidad, expuesta en El poder y el valor (1997). Se trata solamente de una "hipótesis" que valdría la pena desarrollar en un estudio ulterior.

${ }^{52}$ Luis Villoro, "Filosofía y dominación", en El concepto de ideología y otros ensayos (1985a), p. 142.

Diánoia, vol. LII, no. 58 (mayo 2007). 
de otras posibilidades de vida radicalmente distintas. "La vida buena -explica Villoro- es lo otro en el seno de la sociedad existente". ${ }^{53}$ Otra forma de vida, otra forma de sociedad. ${ }^{54}$ La otredad adquiere en este momento un nuevo sentido: la comunidad humana, la vida auténtica, libre y justa como ideal de una razón crítica y práctica a la vez. Se trata de un ideal de la razón porque sólo ella puede asegurar que él no permanezca en un nivel puramente abstracto, "utópico", y pueda fungir así como parámetro orientador (como "ideal normativo") para guiar una transformación eficaz de las condiciones sociales existentes, condiciones que, en cuanto incluyen desde ya la posibilidad del pensamiento crítico, traen efectivamente "en su seno", anuncian o preparan, la posibilidad práctica de "lo nuevo". La filosofía es, para Villoro, visión crítica y anticipación idealizante; pero es, además, compromiso racional. No se conforma con enfrentar a lo existente con lo otro de su ideal, quiere también enfrentar a lo ideal con lo otro de las condiciones reales de vida de los seres humanos. En esto consiste, creemos, el acto esencial y la función primordial de la razón humana: responder a la cuestión: ¿cómo es posible la "vida buena"? ¿Cómo alcanzar una sociedad mejor? ¿Cómo hacer dialogar a lo mismo con lo otro y a lo otro con lo mismo, al valor con el poder y al poder con el valor? En fin, ¿cómo hacer dialogar a la utopía con el presente y al presente con la utopía?

El tema de la comunidad, el ideal de comunidad, ha estado presente en el pensamiento del filósofo mexicano desde sus primeros textos. Como veíamos, el tema se anuncia en sus ensayos de juventud de corte existencialista, alrededor de una concepción humanista, antiegoísta y crítica de la modernidad alienante. Después reaparece en sus observaciones sobre la fenomenología husserliana ${ }^{55}$ y en su reflexión epistemológica. El conocimiento es indefectiblemente una actividad colectiva —no subjetiva, sino intersubjetiva-, y está vinculado necesariamente a un contexto histórico-social y práctico. La inquisición epistemológica, "la sistematización de los conceptos epistémicos —aduce Villoro- no puede ser cerrada: nos remite a los fines y a los valores del individuo y de la sociedad en que está inmerso". ${ }^{56}$ La creencia — punto de partida

${ }^{53}$ Ibid, p. 143.

${ }^{54}$ Sobre la relación intrínseca entre "utopía" y "otredad", y particularmente sobre la utopía como antecedente de la pregunta antropológica fundamental por la otredad cultural, cfr. Esteban Krotz, La otredad cultural. Entre utopía y ciencia.

${ }^{55} \mathrm{Cfr}$. las referencias al tema del otro y la intersubjetividad en el ensayo "La constitución de la realidad en la ciencia pura", en Estudios sobre Husserl (1975a), pp. 99-137, particularmente p. 125 y ss.

${ }^{56}$ Luis Villoro, Creer, saber, conocer, p. 24.

Diánoia, vol. LII, no. 58 (mayo 2007). 
del proceso del conocimiento- no puede ser considerada como una pura "ocurrencia mental", subjetiva y personal, accesible solamente a la introspección privada. Debe ser considerada, estudiada y asumida como un tipo de disposición a actuar; esto es, como un "contenido cognitivo" que se expresa y ha de expresarse en un conjunto de conductas y acciones concomitantes que el sujeto realiza ante sí y ante los demás. Es decir, el sentido de las conductas y acciones de un sujeto sólo pueden ser consideradas como expresiones de una "creencia" - de algo que el sujeto asume sobre el mundo y la realidad- por otros sujetos que las captan, evalúan y comprenden. La creencia es un fenómeno estructuralmente, intrínsecamente, intersubjetivo. ${ }^{57}$ De ahí que, naturalmente, las creencias conformen formas de pensamiento socialmente compartidas y asumidas (las ideologías).

El concepto de comunidad cumple de forma más directa una función relevante en la definición villoriana de las condiciones del "saber". Según nuestro filósofo, el saber consiste en una creencia de la que el sujeto posee razones objetivamente suficientes para sostenerla; esto es, razones que valen para otros sujetos y no sólo para él. "Una razón es objetivamente suficiente -explica Villoro- si es suficiente para cualquier sujeto de la comunidad epistémica pertinente, que la considere."58 Sin esta condición de intersubjetividad no cabría una definición plausible

\footnotetext{
${ }^{57}$ Villoro no insiste suficientemente en la realidad estrictamente intersubjetiva de la "creencia"; aunque ella, al igual que las "actitudes", las "intenciones", sólo "existe" en el mundo común que los individuos forman entre sí y que no posee ninguna clase de sustancialidad. Una perspectiva hermenéutica, que Villoro no asume, permitiría entender el "lugar" propio de la creencia (ni intrapsíquico ni meramente conductista) y evitaría esa recaída en el "naturalismo" que parece desprenderse de la siguiente observación: “Términos como 'actitud', 'creencia', 'intención' se refieren a estados internos del sujeto. Mientras no contemos con una teoría que pudiera tal vez reducirlos a estados físicos o neuronales, no nos queda abierta más que una vía: intentar precisar el significado de los términos a partir de su uso en el lenguaje ordinario" (Villoro, Creer, saber, conocer, p. 56). Las últimas palabras pueden apuntar a la solución del problema: "creencia" no es sólo un concepto de nuestro lenguaje; en realidad, el fenómeno mismo de la creencia no existe sin un lenguaje (o un medio cualquiera de expresión), es decir, sin una comunidad lingüística de comprensión e interpretación. El carácter intencional, performativo incluso, del contenido cognitivo de la creencia (la creencia es una posición, un posicionamiento, del "sujeto" acerca de algo que se asume como existente), planteamiento en el que insiste Villoro, puede entenderse de forma más consistente si nos apoyamos en las tesis hermenéuticas. Además de la obra de Gadamer, cfr. particularmente la reconstrucción lingüística del conocimiento que propone Jürgen Habermas en su Teoría de la acción comunicativa, véase particularmente el volumen. I.

${ }^{58}$ Creer, saber, conocer, p. 148.
} 
del saber. El conocimiento válido es sobre todo un producto históricosocial; no es algo que pueda ser construido y justificado por un sujeto monológico que se atiene únicamente a sus facultades intelectuales y/o a los instrumentos teóricos y conceptuales de su disciplina. Ciertamente, hay que reconocer que la "comunidad epistémica" es una comunidad determinada, formada. No se trata de una comunidad meramente empírica, contingente, sino de una comunidad delimitada por un conjunto de supuestos, de concepciones, de procedimientos metodológicos, etc., que comparten los individuos que la integran. Las comunidades epistémicas tienen una realidad formal y están transidas por el propósito de alcanzar un conocimiento objetivo y válido acerca del mundo. Las condiciones meramente personales y subjetivas de sus miembros se encuentran puestas en suspenso o subsumidas al cumplimiento de aquel propósito.

Sin embargo, no sucede así con lo que Villoro llama las "comunidades sapienciales", donde a la exigencia de objetividad y validez del saber se sobrepone el requerimiento de autenticidad del conocimiento, que éste dé testimonio de la experiencia y la vida de quien lo sostiene: es el tipo de conocimiento que se desprende del acto de "conocer" (conocimiento por la experiencia) y que se consagra tradicionalmente bajo el concepto de "sabiduría". Aquí también, y de un modo más concreto y más real, la comunidad resulta un componente fundamental del sentido y validez del conocimiento, pues, finalmente, las visiones, los ideales y los valores que la sabiduría nos proporciona, dado que no pueden fundamentarse en algún tipo de procedimiento objetivo y metódico, sólo pueden fundarse en la aquiescencia y en el compromiso personal que sean capaces de obtener por parte de un grupo de individuos. La comunidad sapiencial implica la participación concreta del sujeto, donde se ponen en juego tanto sus capacidades intelectuales como su experiencia vital y sus disposiciones afectivas, sus conductas concretas y sus compromisos prácticos.

Ciertamente, las comunidades sapienciales pueden funcionar de forma inauténtica cuando el individuo se adscribe simplemente a un conjunto de dictados y suposiciones sin ponerlos en cuestión ni intentar fundarlos (justificarlos) en su propia vida personal. En este caso, "la sumisión a doctrinas y reglas societarias no se justifica en una experiencia propia, sino en el consenso del grupo". ${ }^{59}$ Operando así, la comunidad sapiencial — religiosa o moral — termina cumpliendo una pura función ideológica: "reiterar las creencias colectivas que permiten mantener la

${ }^{59}$ Ibid., p. 245. 
cohesión de un grupo social y legitimar un sistema de dominación". ${ }^{60}$ Pero cabe siempre la posibilidad de una forma auténtica de la comunidad sapiencial: cuando el individuo está dispuesto a encontrar en su propia experiencia vivida las bases y razones de su decisión de formar parte de determinada comunidad. En este momento se produce una convergencia libre y espontánea entre el individuo y los demás miembros de la comunidad.

Sin embargo, una comunidad humana libre y auténtica permanece sólo como un ideal normativo de la praxis social. Su necesidad y su sentido válido, plantea Villoro, deben ser pensados más allá de la reflexión epistemológica, en el campo de la ética y la filosofía política, en una indagación sobre las condiciones y los límites de la vida y la organización social. En El poder y el valor (1997), Villoro propone la "asociación para la comunidad" - la posibilidad de una comunidad humana equilibrada, libre y justa - como el ideal normativo que debe regir la acción social actual y como criterio o punto de referencia que nos permita evaluar desde el punto de vista del "valor" (y no sólo del "poder") las distintas propuestas de "asociación", esto es, las formas de organización sociopolítica: la asociación para el orden y la asociación para la libertad. "La comunidad está presente como límite posible en toda asociación conforme al valor."61

Cabe subrayar que el ideal comunitarista de Villoro se precisa en la idea de una comunidad libremente integrada. Se opone por igual al predominio del interés individualista - tal como se da en la sociedad moderna - como a la imposición del interés colectivista — tal como se presenta en la mayor parte de las sociedades tradicionales (y tradicionalistas)-. Implica, pues, una solución al conflicto de siempre entre el "egoísmo" y el "altruismo", entre el interés por lo propio y la sumisión a los demás, entre la defensa de la "libertad" y la preeminencia del "orden". Esta solución, esta síntesis, sólo se produce, explica Villoro, "cuando los sujetos de la comunidad incluyen en sus deseos lo deseable para todos"; 62 esto es, cuando el sujeto actúa éticamente y conforme a principios racionales. Entonces descubre que lo mejor para él es desear lo que es bueno para todos:

La comunidad no renuncia a la afirmación de la propia identidad personal - desarrolla Villoro- . Por el contrario, intenta una vía distinta para descubrir el verdadero yo: la ruptura de la obsesión por sí mismo y la apertura a

${ }^{60} \mathrm{Ibid}$.

${ }^{61}$ Luis Villoro, El poder y el valor (1997), p. 360.

${ }^{62}$ Luis Villoro, De la libertad a la comunidad, p. 29. 
los otros, a lo otro. Sabe que cada quien se realizará con mayor plenitud si incluye entre sus fines contribuir al bien del todo al que decide libremente pertenecer. ${ }^{63}$

Ésta es una enseñanza de la "razón" (de la razón valorativa o axiológica), ${ }^{64}$ pero humanamente no puede ser, no ha sido, suficiente para "convencer" al interés egoísta. Es necesario que lo que el entendimiento nos dice se complemente con el compromiso de una voluntad ética, con la disposición a actuar a favor del otro, por amor a los otros. Más allá del orden y de la libertad, la fraternidad, el lazo ético-afectivo se aparece como el valor supremo y la condición de verdadera comunidad. Incluso, como la condición para una realización auténtica de lo que los otros valores propugnan: orden, integración colectiva y libertad, desarrollo autónomo de la individualidad. Únicamente sobre la base del amor fraternal (hablamos de filía más que de eros) ${ }^{65}$ es posible la armonía entre mi libertad y la libertad del otro, entre la autonomía del otro y mi propia autonomía. Únicamente así es posible una humanidad real y auténtica.

Frente a los desmanes de la modernidad, que produce por igual nihilismo existencial y descomposición social, atomización individualista, el ideal comunitarista ha vuelto a ser visitado en la reflexión políticocultural de los últimos tiempos. "En el ocaso del pensamiento moderno, revive la nostalgia por la comunidad perdida", ${ }^{66}$ dice Villoro. No se trataría ciertamente, aclara, de reestablecer las formas tradicionales de la comunidad. No se puede dar marcha atrás a los logros positivos de la sociedad moderna - los preceptos liberales y el valor de la autonomía individual- . Pero sí se puede efectuar una renovación profunda, una reforma radical del pensamiento moderno que permita rememorar

${ }^{63}$ Ibid., pp. 29-30.

${ }^{64}$ Aunque es un punto no desarrollado de forma amplia por Villoro, el planteamiento de que existen diversos "tipos de racionalidad" (teórico-instrumental, práctico-normativo y axiológico-valorativo) es plenamente congruente con su concepción y práctica filosófica. Véase entre otros: L. Villoro, "Sobre relativismo cultural y universalismo ético", en Estado plural, pluralidad de culturas (1998), p. 145; y la ponencia inédita, "Lo racional y lo razonable", Conferencia Inaugural del XIII Congreso de Filosofía de la Asociación Filosófica de México, Morelia, noviembre de 2005.

${ }^{65}$ En un texto inédito, Villoro ha desarrollado el concepto de "filía", de "amistad", a partir de la Ética a Nicómaco, en cuanto condición y forma afectiva de la comunidad humana libre y éticamente fundada.

${ }^{66}$ L. Villoro, El poder y el valor (1997), p. 372. 
y retraer los valores olvidados de la experiencia comunitaria, reinventar la posibilidad de un ser comunitario libremente elegido y construido.

Esa posibilidad no está totalmente perdida; no es un ideal meramente inalcanzable, utópico, en el sentido sólo negativo de la palabra. El valor y el interés por el conocimiento y reconocimiento de los pueblos indígenas de América radica en que ellos han sabido mantener vivo, no sin grandes dificultades y limitaciones, el ideal comunitarista. Porque han insistido en mantener presente una visión del mundo, del cosmos todo, radicalmente contraria a la occidental moderna. Una visión que no está dirigida por el principio de la dominación ni guiada por la estrategia de la ventaja y la posesión; que no opera bajo la lógica de la separación y la exclusión, de la atomización y el extrañamiento, sino bajo la lógica de la integración armónica, de la convivencia pacífica, del servicio, el don y la reciprocidad generalizada con todo lo existente.

Podemos concretar en tres dimensiones la valoración que hace Villoro de las formas de vida y pensamiento de la comunidad indígena: la forma de las relaciones sociales y políticas, la concepción de las relaciones con la naturaleza y los demás seres, y la visión y el sentimiento de lo sagrado.

a) Con respecto al fenómeno del "poder", la comunidad indígena hace prevalecer, dice Villoro, un principio de "contrapoder"; ella misma es "el antídoto del poder particular". ${ }^{67}$ Ningún poder prevalece sobre el de la comunidad y ésta se encarga de evitar toda extralimitación. En realidad, es el sentido del concepto de "poder" lo que aquí cambia, pues éste no consiste en una capacidad de dominar al otro — poder impositivo-, sino en la capacidad de dar o servir al otro - poder expositivo-. Es un poder que significa prestigio, reconocimiento y valoración de todos; responsabilidad, entrega y creatividad. Se sustenta en la comunidad y en la acción recíproca de todos. El propio funcionamiento económico de la comunidad se realiza mediante el don y la reciprocidad, más que mediante el "intercambio", calculador y objetivante (mercantil). Cabe entender el enorme equívoco en que se basó el choque de civilizaciones entre occidentales e indígenas: "mientras los indios daban, en espera de reciprocidad, los conquistadores utilizaban, para adquirir bienes y poderes, el intercambio". ${ }^{68}$

${ }^{67}$ Ibid., p. 365.

${ }^{68}$ Ibid., p. 369.

Diánoia, vol. LII, no. 58 (mayo 2007). 
b) La comunidad tampoco se concibe a sí misma como un segmento puramente "humano"; el vínculo "comunitario" — la comunión - se extiende a las relaciones con el territorio, la tierra, la naturaleza, el cosmos entero. La actitud no objetivante ni cosificante, la comprensión afectiva y cualitativa de lo existente, rige las relaciones del individuo con los demás seres, con los animales, las plantas, la vida toda; obviamente, también con el "extraño", el "extranjero": con todo lo distante e incomprensible que resultase podía tener todavía un "lugar" en la cosmovisión indígena. En la visión occidental, el "otro" sólo podía caber en tanto que definido, subsumido y dominado. Su "diferencia" no ocultaba ningún "misterio", ninguna trascendencia, ningún valor posible.

c) Finalmente, es la concepción de lo "sagrado" lo que marca la diferencia última del espíritu de las culturas indias con Occidente. Para el indígena americano - como para muchos pueblos no occidentales_-, "los dioses son una presencia tangible en todas las cosas [...]. Todo es hierofanía", todo hace presente lo divino. "Lo sagrado está cercano, puede tocarse, sentirse, deglutirse. Está hecho de la misma sustancia de que estamos hechos los hombres. Lo sagrado tiene un aspecto carnal." 69 Hay comunidad y unidad entre lo humano y lo divino; entre lo mismo y lo otro. Ninguna semejanza con las religiones monoteístas del viejo mundo y su concepción ultramundana y abstracta de la divinidad; esto es, su concepción esencialmente "desacralizada" de la naturaleza y de la sociedad, ${ }^{70}$ de la vida, de la acción, del otro y de los otros.

El restablecimiento de la comunidad, el reencuentro con la otredad, concluye Villoro:

liberaría al hombre del regodeo en su propia individualidad, la proyección hacia lo otro de sí le permitiría recuperar la sensación de pertenencia a una totalidad que lo abarca: comunión con la naturaleza, con la comunidad, con el cosmos. Cobrarían entonces nueva dignidad actitudes un tanto olvidadas: entrega, testimonio, humildad, respeto, compasión, fraternidad, amor y justicia. Y quizás esta comunión renovada con el cosmos y con los otros manifestará de nuevo una dimensión de lo Sagrado, no lo Sagrado

${ }^{69}$ Luis Villoro, "La alteridad inaceptable", en Estado plural, pluralidad de culturas (1998), p. 171.

${ }^{70}$ Op. cit., p. 172.

Diánoia, vol. LII, no. 58 (mayo 2007). 
ajeno al hombre, instrumento de las religiones positivas, máscara de opresiones, sino lo Sagrado en el interior de cada hombre y de cada cosa, que se manifiesta en el esplendor y en la unidad del todo. ${ }^{71}$

\section{Conclusión}

El movimiento de la reflexión de Villoro se cierra en el tema que más personal, originaria y profundamente lo ha conmovido y motivado: la relación con el "indígena", el pasmo ante una presencia enigmática y extraña, pero a la vez tan cercana e íntima como un rostro, como la tierra, como el tiempo y la memoria. En una entrevista, Villoro se permite dar cuenta de un "recuerdo de infancia" para explicar su atención y preocupación por la otredad indígena del país. ${ }^{72}$ Seguramente se trata de una experiencia común a muchos mexicanos (criollos y mestizos), quizás a todos.

A lo largo de toda su historia -explica Villoro-, el mexicano se ha visto amagado por la fascinante presencia de lo indígena. A veces, en largas épocas históricas, parece olvidarse de ella; México simula entonces vivir sin ocuparse de la raza de cobre. Pero no puede engañarse a sí mismo por mucho tiempo; apenas ha vuelto las espaldas, cuando siente de nuevo el azoro inquietante de su presencia; $y$, antes de que pueda llegar a olvidarla, vuelve de nuevo sobre ella la mirada, como si algo en la realidad absorta del indio le atrajera invenciblemente. ${ }^{73}$

¿Por qué esta atracción? ¿Por qué este interés problemático y a la vez irrenunciable, inolvidable? Es que pronto se percata el mexicano mestizo (pero también el criollo, el occidental, el "yo moderno") que el indígena - ese sector étnico-social marginado, oscuro y casi reprimido y olvidado- no sólo está "fuera" sino también "dentro" de sí mismo. El indio sería, dice Villoro, "un símbolo inconsciente de esa parte del espíritu que escapa a toda racionalización y se niega a ser iluminada". ${ }^{74}$ Todos llevamos un indio dentro; todos somos un "indio", un "otro"

\footnotetext{
${ }^{71}$ Luis Villoro, El pensamiento moderno (1992), pp. 118-119.

${ }^{72}$ Se trata del encuentro que tuvo Villoro de niño, en la Hacienda de sus padres ubicada en San Luis Potosí, con un grupo de campesinos indígenas. Uno de ellos, un hombre viejo y sencillo, se acercó a Villoro, y en un gesto de humildad excesiva, le besó la mano. Cfr. Imágenes de la filosofía latinoamericana. Luis Villoro, DVD, p. 10 de la reproducción impresa.

${ }^{73}$ Luis Villoro, "Raíz del indigenismo en México" (1952), p. 36.

${ }^{74}$ Ibid, p. 41.
} 
en el corazón de nuestra alma y de nuestro ser propio. ${ }^{75}$ De ahí que el "indigenismo" mexicano no pueda dejar de ser siempre una "construcción", ya una construcción político-discursiva, dirigida a la dominación y al control, ya una construcción simbólico-imaginaria, motivada y orientada por un deseo de liberación, de purificación. "La fascinación por lo indígena expresa, a menudo inconscientemente, el anhelo por identificarnos en lo más auténtico de nuestro ser, liberándonos de toda enajenación."76 La construcción imaginaria del otro, y de lo otro en general, es un elemento constitutivo de nuestra capacidad de autocrítica, de nuestra posibilidad de humildad y de apertura, de "escucha". Es condición también para movilizar nuestro deseo, para darle sentido y figura a nuestros anhelos e ideales.

Pero es condición, precisa Villoro, que seamos conscientes (autoconscientes) de la naturaleza de este proceso, del carácter simbólico de lo indígena, $y$ de la otredad en general (la del tú, la de lo sagrado, la de la comunidad). De otra manera llegamos a "hipostasiar el símbolo en una falsa realidad", nos quedamos en una pura e ideológica mitificación que anula, cierra y reifica la fuerza de nuestro deseo y las posibilidades de nuestra imaginación. Mantener la naturaleza "sana" del humano deseo y de nuestra irrenunciable capacidad de imaginar, cuidar que no se descompongan, que no se atrofien, es también la función de la razón, quizá su función más vital y trascendental. ${ }^{77}$

${ }^{75}$ Villoro tituló uno de sus primeros artículos sobre la cuestión indígena (de 1949): "El indio en el alma del mestizo".

${ }^{76}$ Luis Villoro, "De la función simbólica del mundo indígena" (1993), p. 434.

${ }^{77}$ Al buscar "convertir en razonable lo indecible", al tratar de "comprender", de "interpretar", nuestra experiencia directa y viva, el pensamiento filosófico termina quizá por "profanar" la espontaneidad, el misterio y el encanto de esa experiencia. "¿Pero — pregunta finalmente Villoro- en qué otra forma podría la razón dar testimonio de aquello que la rebasa?". (Luis Villoro, "La mezquita azul" (1985b), p. 28). ¿No empuja - preguntamos nosotros- la concepción de una mediación entre la razón y aquello que la rebasa (lo otro de la razón) a una comprensión esencialmente hermenéutica de la racionalidad, y de la otredad? 


\section{BIBLIOGRAFÍA}

Los textos de Luis Villoro se presentan ordenados cronológicamente del más antiguo al más reciente; no así las obras de otros autores, que han sido ordenadas alfabéticamente.

Textos citados de Luis Villoro

1949, “Soledad y comunión", Filosofía y Letras, vol. 17, no. 33, pp. 115-131. 1950, Los grandes momentos del indigenismo en México, El Colegio Nacional, México; 2a. ed.: México, Secretaria de Educación Pública, 1987.

1952, "Raíz del indigenismo", Cuadernos Americanos, vol. 51, no. 1, 1952, pp. 36-49.

1962, Páginas filosóficas, Universidad Veracruzana, Jalapa.

1965, La idea y el ente en la filosofía de Descartes, Fondo de Cultura Económica, México.

1975a, Estudios sobre Husserl, Universidad Nacional Autónoma de México, México.

1975b, "Lo indecible en el Tractatus", Crítica, vol. 7, no. 19, pp. 5-40.

1982, Creer, saber, conocer, Siglo XXI, México.

1985a, El concepto de ideología y otros ensayos, Fondo de Cultura Económica, México.

1985b, "La mezquita azul: una experiencia de lo otro", Vuelta, no. 106, pp. 1728.

1992, El pensamiento moderno: filosofía del renacimiento, El Colegio Nacional/Fondo de Cultura Económica, México.

1993, "De la función simbólica del mundo indígena”, en Leopoldo Zea (comp.),

Fuentes de la cultura latinoamericana, México, Fondo de Cultura Económica, vol. 2, pp. 428-436.

1997, El poder y el valor. Fundamentos de una ética política, Fondo de Cultura Económica/El Colegio Nacional, México.

1998, Estado plural, pluralidad de cultura, Universidad Nacional Autónoma de México/Paidós, México.

2001, De la libertad a la comunidad, México, Tecnológico de Monterrey/Ariel.

\section{Otros textos citados}

Cabrera, Isabel "La experiencia del silencio", en Ernesto Garzón Valdés y Fernando Salmerón (comps.), Epistemología y cultura. En torno a la obra de Luis Villoro, UNAM, México, 1993, pp. 313-330.

Deleuze, Gilles, Spinoza: filosofía práctica, trad. Antonio Escotado, Tusquets, Barcelona, 1984.

Dussel, Enrique, 1492. El encubrimiento del Otro, Nueva Utopía, Madrid, 1992.

Diánoia, vol. LII, no. 58 (mayo 2007). 
Dussel, Enrique, Filosofía ética latinoamericana. II. Accesos hacia una filosofía de la liberación, Edicol, México, 1977.

Eliade, Mircea, Lo sagrado y lo profano, trad. Luis Gil, Labor, Barcelona, 1967.

Finkielkraut, Alain, La sabiduría del amor, trad. Alfredo Báez, Gedisa, Barcelona, 1985.

Fraisse, Geneviève, La diferencia de los sexos, trad. Horacio Pons, Manantial, Buenos Aires, 1996.

Habermas, Jürgen, Teoría de la acción comunicativa, trad. Manuel Jiménez Redondo, Taurus, Madrid, 2002, 2 vols.

Krotz, Esteban, La otredad cultural. Entre utopía y ciencia, Fondo de Cultura Económica/Universidad Autónoma Metropolitana, México, 2002.

Lévinas, Emmanuel, Totalidad e infinito. Ensayo sobre la exterioridad, trad. Daniel E. Guillet, Sígueme, Salamanca, 1977.

Marcel, Gabriel, Ser y tener, trad. Ana María Sánchez, Caparrós, Madrid, 1996.

Otto, Rudolf, Lo santo. Lo racional y lo irracional en la idea de Dios, trad. Fernando Vela, Alianza, Madrid, 1980.

Spinoza, B. De, La reforma del entendimiento, trad. Alfonso Castaño Piñán, Aguilar, Buenos Aires, 1954.

Subirats, Eduardo, El continente vacío. La conquista del nuevo mundo y la conciencia moderna, Anaya/M. Muchnik, Madrid, 1994.

Todorov, Tzvetan, La conquista de América. El problema del otro, Siglo XXI, México, 1987.

Van der Leeuw, G., Fenomenología de la religión, trad. Ernesto de la Peña, Fondo de Cultura Económica, México, 1964.

Wittgenstein, L., Tractatus logico-philosophicus, trad. Enrique Tierno Galván, Alianza, Madrid, 1973.

Recibido el 25 de agosto de 2006; aceptado el 31 de enero de 2007. 